PERM JOURNAL OF PETROLEUM AND MINING ENGINEERING

ВЕСТНИК ПНИПУ. ГЕОЛОГИЯ. НЕФТЕТАЗОВОЕ И ГОРНОЕ ДЕЛО

ISSN 2224-9923

Volume / Том 20 №1 2020

http://vestnik:pstu.ru/ge

UDC 622.276+622.245.023.623:678.7

Article / Статья

(C) PNRPU / ПНИПУ, 2020

\title{
LABORATORY STUDIES OF POLYMER COMPOSITIONS FOR WELL-KILL UNDER INCREASED FRACTURING
}

\author{
Anton V. Bondarenko, Shamil R. Islamov, Kirill V. Ignatyev, Dmitry V. Mardashov
}

Saint Petersburg Mining University (2 21 ${ }^{\text {st }}$ Line, Vasilyevsky island, Saint Petersburg, 199106, Russian Federation)

\section{ЛАБОРАТОРНЫЕ ИССЛЕДОВАНИЯ ПОЛИМЕРНЫХ СОСТАВОВ ДЛЯ ГЛУШЕНИЯ СКВАЖИН В УСЛОВИЯХ ПОВЫШЕННОЙ ТРЕЩИНОВАТОСТИ}

\section{А.В. Бондаренко, Ш.Р. Исламов, К.В. Игнатьев, Д.В. Мардашов}

Санкт-Петербургский горный университет (199106, Россия, г. Санкт-Петербург, 21-я линия Васильевского острова, 2)

Received / Получена: 02.10.2019. Accepted / Принята: 10.01.2020. Published / Опубликована: 02.03.2020

Key words:

well-kill, well-service, carbonate reservoir, fractured reservoir, problem conditions, abnormal low reservoir pressure, high gas-oil ratio, gas breakthrough, blocking agent, cross-linked polymer compound, laboratory tests, high heat-resistance, breakdown, rheology, effective viscosity.

Ключевые слова:

глушение скважин, подземный ремонт скважин, карбонатный коллектор, трещиноватый коллектор, осложненные условия, аномально низкое пластовое давление, высокий газовый фактор, прорыв газа, блокирующий состав, сшитый полимерный состав, лабораторные исследования, высокая термостабильность, деструкция, реология, эффективная вязкость.
Well-service under increased fracturing is often complicated as early as at the stage of well-killing operations. The presence of cracks in the reservoir formation can result in significant absorption of drilling fluid, as well as in bottomhole gas breakthrough. The laboratory studies are required to develop a blocking agent for reliable isolation of highly permeable reservoir intervals without a negative impact on the reservoir porosity and permeability and in compliance with operational safety requirements.

For the purpose of this work, the physical, chemical and rheological properties of frame-forming and gel-forming compositions, which are cross-linked systems prepared on the basis of soluble silicates, have been studied. The well-killing technology implies their consecutive injection into the well. The reviewed compounds have proven their applicability in a wide range of reservoir temperatures, which provided for the possibility of their injection into a standard well and flushing into the bottomhole formation zone due to low viscosity and slowed cross-linking. Breaker application allows us to almost completely eliminate negative impact of this technology on filtration characteristics of the bottomhole formation zone after well-killing.

The studies conducted within the scope of this work have shown application efficiency of blocking polymer compounds and opened new directions for further researches, including the necessity to undertake a sequence of laboratory and field tests of the reviewed agents, which will enable to select and validate optimal technological and economic parameters of the operation.

The results obtained can be used to improve the efficiency of oil and gas well-kills under increased fracturing during wellservice operations.

Подземный ремонт скважин в условиях повышенной трещиноватости зачастую сопровождается осложнениями еще на этапе проведения операций глушения скважин. Наличие трещин в породе-коллекторе может привести не только к значительным поглощениям технологической жидкости, но и к прорыву газа к забою скважины. Необходимо проведение лабораторных исследований с целью разработки блокирующего состава для надежной изоляции высокопроницаемых интервалов пластов, не оказывающего отрицательного воздействия на фильтрационно-емкостные свойства коллектора и отвечающего требованиям безопасности при проведении работ. В рамках данной работы изучены физико-химические и реологические свойства каркасообразующего и гелеобразующего составов, представляющих собой сшитые системы, приготовленные на основе растворимых силикатов. Технология проведения глушения предполагает их последовательную закачку в скважину. Рассматриваемые составы показали технологичность их применения в широком диапазоне пластовых температур, заключающуюся в возможности их закачки в типовую скважину и продавки в призабойную зону пласта за счет низкой вязкости и замедленной скорости сшивки. Применение деструктора позволяет почти полностью исключить негативное влияние данной технологии на фильтрационные характеристики призабойной зоны пласта после глушения.

Исследования, проведенные в данной работе, показали эффективность применения блокирующих полимерных составов, а также открыли новые направления для дальнейших исследований, а именно - необходимость проведения цикла лабораторных и промысловых испытаний рассмотренных составов, что позволит выбрать и обосновать оптимальные технологические и экономические параметры проводимой операции.

Полученные результаты могут быть применены для повышения эффективности глушения нефтяных и газовых скважин в условиях повышенной трещиноватости при проведении ремонтных работ.

Anton V. Bondarenko - PhD student at the Department of Reservoir Engineering (tel.: +007 812328 84 20, e-mail: Bondarenko_AV@pers.spmi.ru).

Shamil R. Islamov - PhD student at the Department of Reservoir Engineering (tel.: +007 81232884 20, e-mail: Islamov_SR@pers.spmi.ru).

Kirill V. Ignatyev - BSc student (tel.: +007812 32884 20, e-mail: Ignatyev_KV@pers.spmi.ru).

Dmitry V. Mardashov (Author ID in Scopus: 55596392500) - PhD in Engineering, Associate Professor at the Department of Reservoir Engineering (tel.: +007 8123288420 , e-mail: Mardashov_DV@pers.spmi.ru). The contact person for correspondance.

Бондаренко Антон Владимирович - аспирант кафедры разработки и эксплуатации нефтяных и газовых месторождений (тел.: +007 8123288420 , e-mail: Bondarenko_AV@pers.spmi.ru).

Исламов Шамиль Расихович - аспирант кафедры разработки и эксплуатации нефтяных и газовых месторождений (тел.: +007 8123288420 , e-mail: Islamov SR@pers.spmi.ru).

Игнатьев Кирилл Валерьевич - бакалавр кафедры разработки и эксплуатации нефтяных и газовых месторождений (тел.: +007812 3288420 , e-mail: Ignatyev_KV@pers.spmi.ru).

Мардашов Дмитрий Владимирович - кандидат технических наук, доцент кафедры разработки и эксплуатации нефтяных и газовых месторождений (тел.: +007 8123288420 , e-mail: Mardashov_DV@pers.spmi.ru). Контактное лицо для переписки. 


\section{Introduction}

Based on the estimate of reserves, carbonate reservoirs currently account for about $60 \%$ of hydrocarbon fields and approximately the same amount of oil production in the world. Development of such reservoirs is complicated by the presence of an extensive network of natural and artificial (as a result of hydraulic fracturing) fractures, high heterogeneity, complex structure of pore space, hydrophobic properties of reservoir formations, and abnormal low reservoir pressure.

The reviewed characteristic features of carbonate reservoirs can lead to low reservoir coverage, low displacement efficiency, rapid watercuts, gas breakthrough, and, as a result, a rapid drop in oil production [1-9].

The presence of formations with similar characteristics in the field determines a particular differentiated approach to the planning of wellkilling operations related to the development and selection of a blocking agent. Correct selection of blocking agents for well-killing requires comprehensive laboratory tests for specific objects of planned application.

Non-compliance with the above conditions when planning well interventions can result in the loss of significant amounts of drilling fluids, extended workover and well start-up time, which will eventually increase the cost of underground operations [10-12].

The advanced solution in the development of blocking fluids is the use of cross-linked polymer compounds with time-based gelation. Viscosity fluctuation rate can be adjusted for more efficient process operations.

The technologies using the described polymer compositions have proved to be a reliable method of isolating high-permeability formation intervals in order to prevent water and gas breakthrough into production wells [13-15].

In the context of this work, physical, chemical and rheological properties of frame-forming and gel-forming compounds as blocking polymer fluids for well-killing have been selected and studied.

These compounds are cross-linked systems prepared on the basis of soluble silicates. In this case, silicate gel is formed when an aqueous solution with relatively high $\mathrm{pH}$ value, containing a sufficient amount of orthosilic acid monomer or orthosilic acid oligomers, experiences its $\mathrm{pH}$ value reduction or is exposed to hard cations $[16,17]$.

The frame-forming compound is a nontransparent heterogeneous liquid of white colour. When injected into the reservoir, the liquid phase is hardened and the dry residue is coagulated under elevated temperatures, creating a strong frameforming screen to isolate the intervals with increased fracturing. Such compound feature allows reducing losses of drilling fluid injected into the well during well-killing.

In its turn, the gel-forming compound is a transparent homogeneous liquid that, due to its increased viscosity, has a low formation filtration rate and is able to prevent gas breakthrough under high gas-oil ratio conditions. In our case, it was prepared in two modifications with a gel-forming agent for low $\left(20^{\circ} \mathrm{C}\right)$ and high $\left(90^{\circ} \mathrm{C}\right)$ temperatures.

The technology of well-killing during their underground workover involves consecutive injection of the frame-forming and gel-forming compounds into the well.

The laboratory physical, chemical and rheological studies of compounds consisted of several consecutive stages:

1) density determination;

2) evaluation of heat resistance;

3) evaluation of breakability;

4) determination of effective viscosity and static shear stress (SSS); and

5) determination of gelation time of crosslinked compositions.

\section{Physical and Chemical Studies of Compounds}

The density of the frame-forming and gelforming compounds was determined by pycnometer method as per [18] and amounted to 1.045 and $1.015 \mathrm{~kg} / \mathrm{m}^{3}$ for low temperatures, and $1.022 \mathrm{~kg} / \mathrm{m}^{3}$ for high temperatures.

Such density value of the studied compounds allows applying them at normal and reduced formation pressure [19-22].

To measure the heat resistance, the prepared compound was kept in thermostat at the 
temperatures from $20{ }^{\circ} \mathrm{C}$ or $90{ }^{\circ} \mathrm{C}$ for three days (average duration of servicing operations). Next, the condition of the composition under study and the change in appearance were visually estimated. In case of water phase separation, breaking and sedimentation, the compound was considered unstable [23-28].

Following the heat resistance estimation of the frame-forming compound (Table 1), it was established that 15 minutes after the composition was prepared, both at $20{ }^{\circ} \mathrm{C}$ and at $90{ }^{\circ} \mathrm{C}$, up to $20 \%$ and $25 \%$ of water was released, respectively. Throughout further thermostatic control, the amount of water released remained practically unchanged. At the same time, manufacturer of the frame-forming compound allows for water release from the composition volume in small amounts. Therefore, it was decided that the frame-forming compound is heat-stable at $20{ }^{\circ} \mathrm{C}$ and $90{ }^{\circ} \mathrm{C}$ and can retain its physical and chemical properties during servicing operations in the well.

Table 1

Heat-Resistance Properties of the Frame-Forming and Gel-Forming Compounds

\begin{tabular}{|l|c|c|c|}
\hline Compound & $\begin{array}{c}\text { Heat Resistance } \\
\text { at } 20{ }^{\circ} \mathrm{C} \text { over } 3 \\
\text { days }\end{array}$ & $\begin{array}{c}\text { Heat } \\
\text { Resistance at } \\
90{ }^{\circ} \mathrm{C} \text { over } 3 \\
\text { days }\end{array}$ & Note \\
\hline Frame-Forming & Yes & Yes & $\begin{array}{c}\text { Release up } \\
\text { to } 20 \% \text { and } \\
25 \% \text { of water, } \\
\text { respectively }\end{array}$ \\
\hline Gel-Forming & Yes & Yes & - \\
\hline
\end{tabular}

At the same time, during the thermostatic control of the gel-forming compound, no visible changes in appearance were observed over the entire period under study.

It should be noted that the requirement to such compounds at well-killing is their full or partial breaking on exposure to breaker. The compounds failing to meet the given conditions cannot be recommended for application, since it deteriorates the reservoir's permeability properties and complicates the well development and start-up after servicing.

Breakability of the frame-forming and gelforming compounds was estimated visually at 20
${ }^{\circ} \mathrm{C}$ and $90{ }^{\circ} \mathrm{C}$ over 24 hours by mixing the breaker with the reviewed blocking agents at a ratio of $1: 1$. $10 \%$ aqueous sodium hydroxide solution was used as a breaker for the gel-forming compound, whereas a mixture of $12 \%$ hydrochloric acid and $5 \%$ hydrofluoric acid was used to break the frameforming compound.

Following the results of breaking estimation of the frame-forming and gel-forming compounds (Table 2), it was established that these compounds can be recommended for use at well-killing.

\section{Determination of Rheological Properties of the Compounds}

The study of rheological properties of the frame-forming and gel-forming compounds consisted in measuring the following parameters:

- effective viscosity at $300 \mathrm{rpm}$;

- 'viscosity curves' (dependence of effective viscosity on shear rate or rotor speed);

- static shear stress after gel-formation of cross-linked compositions at controlled shear rate by plotting the dependency of shear stress $\tau$ on shear rate $D$, determination of shear stress value at which breaking and motion of the compound structure starts;

- gelation time of cross-linked compositions under dynamic conditions by measuring effective viscosity $\mu_{\text {eff }}$ of the compound over time at a given shear rate equal to the rate of the compound injection into the well, and under static conditions of oscillating stresses by measuring complex viscosity over time.

Plotting a viscosity curve and determining static shear stress were conducted for the frameforming and gel-forming compounds. Static shear stress determines the initial pressure gradient, at which breaking and motion of the composition structure take place [18, 29-35].

Experiments to determine the gelation time were carried out only for cross-linked compositions that are nonlinear gels.

Rheological properties were determined as per [36] with a rotary automated viscometer Rheotest RN 4.1 (Fig. 1). Measurements were performed using a cylinder measuring system. 
Evaluation of Breaking Processes of the Frame-Forming and Gel-Forming Compounds

\begin{tabular}{|l|c|c|c|c|c|}
\hline \multirow{2}{*}{ Blocking Compound } & $\begin{array}{c}\text { Temperature, } \\
{ }^{\circ} \mathrm{C}\end{array}$ & Breaking Result & $\begin{array}{c}\text { Breaking Time, } \\
\text { hrs }\end{array}$ & Breaker & $\begin{array}{c}\text { Recommendation } \\
\text { for use }\end{array}$ \\
\hline \multirow{2}{*}{ Frame-Forming } & 20 & Partly & $\begin{array}{c}1(50 \%) \\
24(75 \%)\end{array}$ & $12 \% \mathrm{HCl}+5 \% \mathrm{HF}$ & Recommended \\
\cline { 2 - 6 } & 90 & Partly & $1(75 \%)$ & $12 \% \mathrm{HCl}+5 \% \mathrm{HF}$ & Recommended \\
\hline \multirow{2}{*}{ Gel-Forming } & 20 & Fully & 3 & $10 \% \mathrm{NaOH}$ aqueous solution & Recommended \\
\cline { 2 - 6 } & 90 & Fully & 1 & $10 \% \mathrm{NaOH}$ aqueous solution & Recommended \\
\hline
\end{tabular}

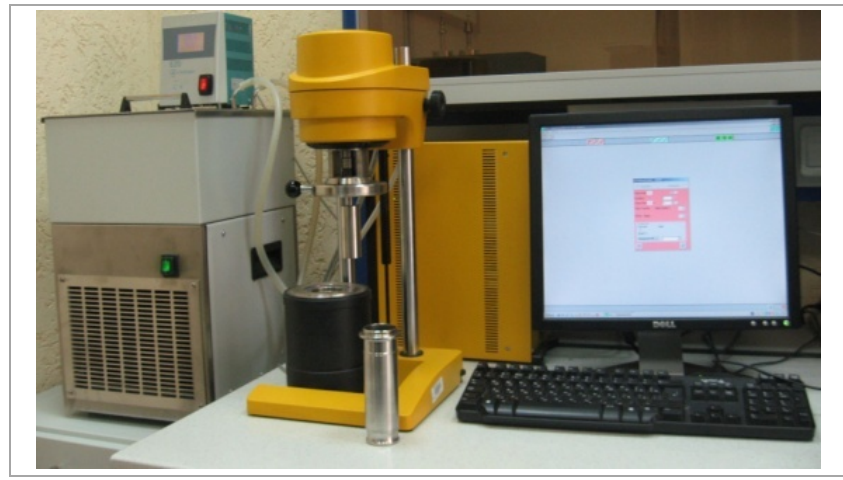

Fig. 1. Rotary automated viscometer Rheotest RN 4.1

I. The test procedure for linear (non-crosslinked) compounds.

1. Process simulation of compound motion start (breaking of compound structure). Static shear stress is determined by plotting the dependency of shear stress on shear rate at controlled shear rate. Static shear stress is equal to the value of shear stress $\tau$ preceding the compound structure breaking, and it indicates the compound motion start. Experimental conditions:

- preliminary compound hold in the measuring cell for $15 \mathrm{~min}$;

- experiment time $t=0-500 \mathrm{sec}$;

- shear stress $\tau=0-2000 \mathrm{~Pa}$;

- temperature $20^{\circ} \mathrm{C}$ and $90{ }^{\circ} \mathrm{C}$, respectively.

2. Effective viscosity was determined at controlled shear rate: viscosity curve (CR test Controlled Rate). The essence of the investigation method was to establish the dependency of effective viscosity (shear stress) on shear rate (rotation speed) with a gradual increase of the latter parameter from 0 to $300 \mathrm{~s}^{-1}$. Experimental conditions:
- time $t=0-300 \mathrm{sec}$;

- shear rate $\gamma=0-300 \mathrm{~s}^{-1}$; and

- temperature $20^{\circ} \mathrm{C}$ and $90{ }^{\circ} \mathrm{C}$, respectively.

II. Due to the fact that viscosity of the gel-forming compound changes over time, the decision was made to conduct a staged study of rheological properties according to the following scheme [37-42]:

1. Compound condition simulation immediately after preparation at wellhead to estimate filterability in annular space or in a tubing string. Compound effective viscosity at different shear rates is determined by establishing the viscosity curve. Experimental conditions:

- time $t=0-300 \mathrm{sec}$;

- shear rate $\gamma=0-300 \mathrm{~s}^{-1}$; and

- temperature $20^{\circ} \mathrm{C}$.

2. Simulation of compound injection along the annular space into the well subject to uniform temperature change along the wellbore. Gelation time at constant shear rate is determined. Experimental conditions:

- experiment time $t=85 \mathrm{~min}$;

- shear rate $\gamma=21.8 \mathrm{~s}^{-1}$; and

- temperature $T=20^{\circ} \mathrm{C}-90{ }^{\circ} \mathrm{C}$ (for the compound applicable at $20{ }^{\circ} \mathrm{C}$, the experimental temperature $T=20^{\circ} \mathrm{C}$ ).

3. Process simulation of compound injection into the production string space. Gelation time at constant shear rate is being determined. Experimental conditions:

- experiment time $t=15 \mathrm{~min}$;

- shear rate $\gamma=7.1 \mathrm{~s}^{-1}$

- temperature $T=90{ }^{\circ} \mathrm{C}$ (for the compound applicable at $20{ }^{\circ} \mathrm{C}$, the experimental temperature $T=20^{\circ} \mathrm{C}$ ). 
4. Process simulation of the compound holding for the reaction time (the end of cross-linking process) at formation temperature. Gelation time under static conditions of oscillating stresses is determined [43-45]. Experimental conditions:

- time $t=3$ hours;

- rotor oscillation frequency $f=1 \mathrm{~Hz}$;

- voltage module $G=10 \mathrm{~Pa}$;

- temperature $90{ }^{\circ} \mathrm{C}$ (for the compound applicable at $20{ }^{\circ} \mathrm{C}$, the experimental temperature $T=20^{\circ} \mathrm{C}$ ).

5. Process simulation of the compound motion start (compound structure breaking). Static shear stress is determined by plotting the dependency of shear stress on shear rate at the controlled shear rate. Experimental conditions:

- time $t=0-500 \mathrm{sec}$;

- shear stress $\tau=0-2000 \mathrm{~Pa}$.

- temperature $90{ }^{\circ} \mathrm{C}$ (for the compound applicable at $20{ }^{\circ} \mathrm{C}$, the experimental temperature $T=20^{\circ} \mathrm{C}$ ).

6. Compound condition simulation after injection into the well to estimate its effective viscosity change. Effective viscosity of the compound at different shear rates is determined by establishing the viscosity curve. Experimental conditions:

- time $t=0-300 \mathrm{sec}$;

- shear rate $\gamma=0-300 \mathrm{~s}^{-1}$;

- temperature $90{ }^{\circ} \mathrm{C}$ (for the compound applicable at $20{ }^{\circ} \mathrm{C}$, the experimental temperature $T=20^{\circ} \mathrm{C}$ ).

The summarized results of rheological studies of compounds are given in Table 3 .

As a result of cross-linking time determination during the gel-forming compound injection simulation (applied for $20{ }^{\circ} \mathrm{C}$ ) into a simulated well, the following has been established:

- the compound cross-linking process starts during its injection into the annular space. Gelation start induction period is approx. 40 minutes after the compound preparation;

- the compound cross-linking process ends after its injection into the well, during the well shut-in period. Gelation end induction period is approx. 2 hours $20 \mathrm{~min}$ after the compound preparation.
Table 3

Rheological Studies of the Frame-Forming and Gel-Forming Compounds

\begin{tabular}{|l|c|c|c|c|}
\hline Compound & $\begin{array}{c}\text { Temper } \\
\text { ature, } \\
{ }^{\circ} \mathrm{C}\end{array}$ & $\begin{array}{c}\text { Effective } \\
\text { viscosity, } \\
\mathrm{mPa} \cdot \mathrm{s}, \\
\text { after } \\
\text { preparation } \\
\text { at } N=300 \mathrm{rpm}\end{array}$ & $\begin{array}{c}\text { Effective } \\
\text { viscosity, } \mathrm{mPa} \cdot \mathrm{s}, \\
\text { after cross- } \\
\text { linking } \\
\text { at } N=300 \mathrm{rpm}\end{array}$ & $\begin{array}{c}\mathrm{SSS}, \\
\mathrm{Pa}\end{array}$ \\
\hline $\begin{array}{l}\text { Frame- } \\
\text { forming }\end{array}$ & 90 & 27 & - & 2.66 \\
\cline { 2 - 5 } Gel-forming & 90 & 64 & - & 3.38 \\
\cline { 2 - 5 } & 20 & 10.7 & 17.4 & 126 \\
\hline
\end{tabular}

Note: '-' means that the effective viscosity for the given compounds has not been measured because they are not "crosslinked' and their viscosity is time-independent.

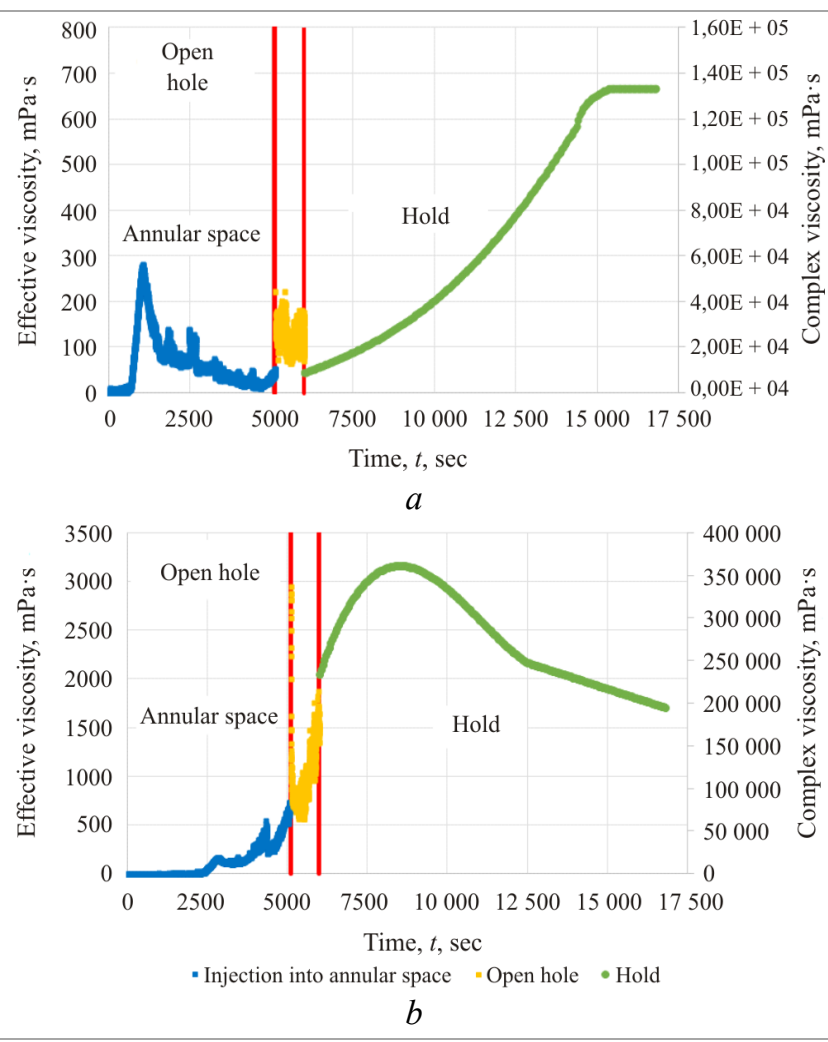

Fig. 2. Dynamics of effective and complex viscosity of the gel-forming compound: $a-90{ }^{\circ} \mathrm{C} ; b-20{ }^{\circ} \mathrm{C}$

The results of gelation time determination under conditions of cross-linked compounds injection are shown in Fig. 2.

Based on the results published in [34], the higher the static shear stress, the higher is the pressure gradient the blocking agent is able to withstand without breaking. The same conclusions are true when the effective viscosity increases, since its structural strength grows. 
Based on cross-linking time determination during the gel-forming compound injection simulation (applied for $90{ }^{\circ} \mathrm{C}$ ) into a simulated well, we came to the following conclusions:

- the cross-linking process starts during the compound injection into the annular space. Gelation start induction period is approx. 12 minutes after the compound preparation;

- the compound cross-linking process ends during its injection into the annular space. Gelation end induction period is approx. 18 minutes after the compound preparation. After the compound injection into the well, during the well shut-in period, structuring is observed, characterized by an increase in complex viscosity, which ends 4 hours after the compound preparation. In order to increase the process efficiency (for example, to prevent mechanical breaking of the gel during its injection into the well) of well-killing using the gel-forming compound applied for $90{ }^{\circ} \mathrm{C}$, it is recommended to adjust the component composition so that the gelation process is completed after the entire compound is injected into the well.

\section{Conclusion}

The following results were obtained based on the physical, chemical and rheological studies of frame-forming and gel-forming compounds:

1. The compounds applied at low $\left(20^{\circ} \mathrm{C}\right)$ and high $\left(90^{\circ} \mathrm{C}\right)$ temperatures are heat-resistant over the entire period of time ( 3 days).

2. The results of breaking estimation of the frame-forming and gel-forming compounds have shown the following:

- the gel-forming compound is broken completely by $10 \%$ aqueous solution of $\mathrm{NaOH}$ over 1 and 3 hours at $90{ }^{\circ} \mathrm{C}$ and $20{ }^{\circ} \mathrm{C}$, respectively;
- the frame-forming compound is broken by $75 \%$ by a mixture of $12 \%$ hydrochloric acid and $5 \%$ hydrofluoric acid (mud acid) over 1 and 24 hours at $90{ }^{\circ} \mathrm{C}$ and $20^{\circ} \mathrm{C}$, respectively.

3. The gel-forming (8 and $10.7 \mathrm{MPa} \cdot \mathrm{s})$ and frame-forming (64 and $27 \mathrm{MPa} \cdot \mathrm{s}$ ) compounds feature low effective viscosity after preparation at $20{ }^{\circ} \mathrm{C}$ and $90{ }^{\circ} \mathrm{C}$, respectively, which allows for the conclusion of their applicability for the well injection.

4. The gel-forming compounds can have high blocking ability as their SSS is $648 \mathrm{~Pa}$ at low temperatures $\left(20{ }^{\circ} \mathrm{C}\right)$ and $126 \mathrm{~Pa}$ at high temperatures $\left(90^{\circ} \mathrm{C}\right)$.

The physical, chemical and rheological studies of the frame-forming and gel-forming compounds have shown their applicability at reservoir temperatures from $20{ }^{\circ} \mathrm{C}$ to $90{ }^{\circ} \mathrm{C}$, involving their injection into a standard well and flushing into the bottomhole formation zone, due to their low viscosity after preparation and slow cross-linking. However, based on the studies conducted, it is recommended to adjust the contents of gel-forming compound composition (applied for $90{ }^{\circ} \mathrm{C}$ ) so that the gelation process is finished after the complete injection of the compound into the well.

Besides, the breakers application allows us to reduce the negative impact of this technology on filtration characteristics of the bottomhole formation zone after well-killing due to the reduced coefficient of the relative permeability curve and pressure gradient of the oil filtration start during well 'development'.

To address the problem of well-killing in complex geological and physical conditions of carbonate reservoir development it is necessary to conduct a sequence of laboratory and field tests of the reviewed compounds, which will enable one to select and validate optimal technological and economic parameters of the operation.

\section{Refefrences}

1. Islamov S.R., Bondarenko A.V., Korobov G.Y., Podoprigora D.G. Complex algorithm for developing effective kill fluids for oil and gas condensate reservoirs. International Journal of Civil Engineering and Technology. India, IAEME Publication, 2019, 10 (01), pp.2697-2713.
2. Islamov Sh.R., Bondarenko A.V., Mardashov D.V. Podbor reagentov-emulgatorov dlia prigotovleniia invertno-emulsionnykh rastvorov [A selection of emulsifiers for preparation of invert emulsion drilling fluids]. Inzhener-neftianik, 2018, no.4, pp.10-15. 
3. Orlov G.A., Kendis M.Sh., Glushchenko V.N. Primenenie obratnykh emulsii $\mathrm{V}$ neftedobyche [The use of inverse emulsions in oil production]. Moscow, Nedra, 1991, 224 p.

4. Boiko V.S. Razrabotka i ekspluatatsiia neftianykh mestorozhdenii [Development and exploitation of oil fields]. Moscow, Nedra, 1990, 427 p.

5. Chernitskii A.V. Geologicheskoe modelirovanie neftianykh zalezhei massivnogo tipa $\mathrm{v}$ treshchinovatykh kollektorakh [Geological modeling of massive oil deposits in fractured reservoirs]. Moscow, RMNTK "Nefteotdacha", 2002, $254 \mathrm{p}$.

6. Vikrant Wagle, Abdullah S. Al-Yami, Ali AlSafran. Designing invert emulsion drilling fluids for HTPT conditions. SPE Kingdom of Saudi Arabia Annual Technical Symposium and Exhibition. Dammam: Society of Petroleum Engineer, 2018. DOI: 10.2118/192192-MS

7. Hon Chung Lau. Laboratory development and field testing of succinoglycan as a fluid-losscontrol fluid. SPE Drilling \& Completion. Aberdeen, Society of Petroleum Engineer, 1994. DOI: $10.2118 / 26724-P A$

8. Petrov N.A., Solovev A.Ia., Sultanov V.G. Emulsionnye rastvory $\mathrm{V}$ neftegazovykh protsessakh [Emulsion solutions in oil and gas processes]. Moscow, Khimia, 2008, $440 \mathrm{p}$.

9. Zhelonin P.V., Mukhametshin D.M., Archikov A.B., Zvonarev A.N., Kraevskii N.N., Gusakov V.N. Obosnovanie algoritma vybora tekhnologii glusheniia skvazhin [Justification of the algorithm for selecting well killing technologies]. Nauchno-tekhnicheskii Vestnik PAO NK “Rosneft”, 2015, no.2, pp.76-81.

10. Legkokonets V.A., Islamov S.R., Mardashov D.V. Multifactor analysis of well killing operations on oil and gas condensate field with a fractured reservoir. Topical Issues of Rational Use of Mineral Resources. London, CRC Press, 2018, pp.111-118.

11. Basarygin Iu.M. Tekhnologicheskie osnovy osvoeniia i glusheniia neftianykh i gazovykh skvazhin [Technological fundamentals of development and killing of oil and gas wells: textbook for universities]. Moscow, Nedra, 2001, $543 \mathrm{p}$.

12. Riabokon S.A., Volters A.A., Surkov V.B., Glushchenko V.N. Zhidkosti glusheniia dlia remonta skvazhin i ikh vliianie na kollektorskie svoistva plasta [Well killing fluids for well service operation and their effect on reservoir properties]. OI. Seriia "Neftepromyslovoe delo". Moscow, VNIIOENG, 1989, iss.19, 42 p.

13. Egorova E.V., Vybornova T.S. Analiz opyta razrabotki zhidkostei dlia glusheniia i promyvki skvazhin pri provedenii remontnovosstanovitelnykh rabot [Analysis of experience in the development of well killing fluids and flushing wells during repair and renewal operations]. Bulatovskie chteniia, 2018, vol.2, part 2, pp.109-112.

14. Mardashov D.V. Obosnovanie tekhnologii regulirovaniia filtratsionnykh kharakteristik prizaboinoi zony skvazhin pri podzemnom remonte [Substantiation of technologies for regulating the filtration characteristics of the bottom-hole zone of wells during underground repairs]. Abstract of $\mathrm{Ph}$. D. thesis. Saint Petersburg, 2008, $130 \mathrm{p}$.

15. Gumerova G.R., Iarkeeva N.R. Tekhnologiia primeneniia sshitykh polimernykh sostavov [Technology of application of crosslinked polymeric compositions]. Neftegazovoe delo, 2017, no.2, pp.63-79.

16. Leik L. Spravochnik inzhenera-neftianika. Inzhiniring rezervuarov [Handbook of an oil engineer. Reservoir engineering]. Moscow, Institut kompiuternykh issledovanii, 2018, 1074 p.

17. Bouts M.N., Ruud A.T., Samuel A.J. Time delayed and low-impairment fluidloss control using a succinoglycan biopolymer with an internal acid breaker. SPE Journal. Texas: Society of Petroleum Engineer, 1997. DOI: $10.2118 / 31085-\mathrm{PA}$

18. GOST 3900-85. Neft i nefteprodukty. Metody opredeleniia plotnosti [Oil and oil products. Density determination methods]. Moscow, Izdatelstvo standartov, 2006, $37 \mathrm{p}$.

19. Foxenberg W.E., Ali S.A., Ke M. Effects of completion fluid loss on well productivity. SPE Formation Damage Control Symposium. 
Lafayette: Society of Petroleum Engineer, 1996. DOI: 10.2118/31137-MS

20. Chesser B.G., Nelson G.F. Applications of weighted acid-soluble workover fluids. Journal of Petroleum Technology. New York: Society of Petroleum Engineer, 1979. DOI: $10.2118 / 7008-P A$

21. Demakhin S.A., Merkulov A.P., Kasianov D.N., Malaiko S.V., Anfinogentov D.A., Chumakov E.M. Glushenie skvazhin blok-pachkami - effektivnoe sredstvo sokhraneniia filtratsionnykh svoistv produktivnogo plast [Block killing wells is an effective means of preserving the filtration properties of the reservoir]. Neft $i$ gaz Evrazii, 2014, no.8-9, pp.56-57.

22. Bondarenko A.V., Islamov Sh.R., Mardashov D.V. Oblast effektivnogo primeneniia zhidkostei glusheniia neftianykh i gazovykh skvazhin [Field of effective use of killing fluids for oil and gas wells]. Materialy mezhdunarodnoi nauchno-prakticheskoi konferentsii "Dostizheniia, problemy $i$ perspektivy razvitiia neftegazovoi otrasli". Almetevsk, Almetevskii gosudarstvennyi neftianoi institut, 2017, vol.1, pp.216-221.

23. Ovchinnikov V.P. Zhidkosti i tekhnologii glusheniia skvazhin [Killing fluids and technologies]. Tiumen, TiumGNGU, 2013, 96 p.

24. Dmitruk V.V., Rakhimov S.N., Boiarkin A.A., Shtakhov E.N. Povyshenie effektivnosti glusheniia skvazhin urengoiskogo mestorozhdeniia [Improving the effectiveness of killing wells of Urengoyskoye field]. Oil industry, 2009, no.4, pp.2-4.

25. Bakirova A.D., Shaliapin D.V., Dvoinikov M.V. Issledovanie viazkouprugikh sostavov v kachestve zhidkosti glusheniia skvazhin [Reseach of viscoelastic composition as a wellkilling fluid]. Akademicheskii zhurnal Zapadnoi Sibiri, 2018, no.4, pp.44-45.

26. Zharikov M.G., Li G.S., Kopylov A.I., Minaeva E.V., Skotnov S.N. Razrabotka i ispytanie zhidkostei glusheniia i blokiruiushchikh sostavov na uglevodorodnoi osnove pri kapitalnom remonte gazovykh skvazhin Urengoiskogo NGKM [Development and testing of wells' hydrocarbon based killing fluids and blocking compositions during gas wells overhaul in Urengoy oil and gascondensate fields]. Stroitelstvo neftianykh $i$ gazovykh skvazhin na sushe i na more, 2018, no.1, pp.20-23.

27. Bondarenko A.V., Islamov S.R., Mardashov D.V. Features of oil well killing in abnormal carbonate reservoirs operating conditions. 15th Conference and Exhibition Engineering and Mining Geophysics 2019. Gelendzhik, European Association of Geoscientists and Engineers, 2019, pp.629-633.

28. Sharath S., Donald W., Jonathan W. Acidsoluble lost circulation material for use in large, naturally fractured formations and reservoirs. $S P E$ Middle East Oil \& Gas Show and Conference. Manama, Society of Petroleum Engineer. 2017. DOI: $10.2118 / 183808-M S$

29. Riabokon S.A. Tekhnologicheskie zhidkosti dlia zakanchivaniia i remonta skvazhin [Process fluids for completion and workover operation]. Krasnodar, Burenie, 2009, 337 p.

30. Tokunov V.I. Tekhnologicheskie zhidkosti i sostavy dlia povysheniia produktivnosti neftianykh i gazovykh skvazhin [Process fluids and compositions for increasing the productivity of oil and gas wells]. Moscow, Nedra, 2004, 711 p.

31. Fischer P.W., Gallus J.P., Krueger R.F., Pye D.S., Simmons F.J., Talley B.E. An organic "Clay Substitute" for nondamaging water base drilling and completion fluids. Fall Meeting of the Society of Petroleum Engineers of AIME. Nevada, Society of Petroleum Engineer, 1973. DOI: $10.2118 / 4651-\mathrm{MS}$

32. Dorman J., Udvary F. Comparative evaluation of temporary blocking fluid systems for controlling fluid loss through perforations. SPE Formation Damage Control Symposium. Lafayette, Society of Petroleum Engineer, 1996. DOI: 10.2118/31081-MS

33. Dandekar A.Y. Petroleum reservoir rock and fluid properties. Boca Raton, CRC press, 2013, $544 \mathrm{p}$.

34. Strizhnev K.V. Remontno-izoliatsionnye raboty $\mathrm{v}$ skvazhinakh: teoriia i praktika [Repair and insulation works in wells: Theory and practice]. Saint Petersburg, Nedra, 2010, 560 p.

35. Islamov S.R., Bondarenko A.V., Mardashov D.V. Substantiation of a well killing technology for fractured carbonate reservoirs. Youth Technical Sessions Proceedings: VI Youth 
Forum of the World Petroleum Council - Future Leaders Forum. London, CRC Press, 2019, pp.256-264.

36. GOST 1929-87. Nefteprodukty. Metody opredeleniia dinamicheskoi viazkosti na rotatsionnom viskozimetre [Oil products. Methods for determination of dynamic viscosity on a rotational viscometer]. Moscow, Izdatelstvo standartov, 2002, $7 \mathrm{p}$.

37. Raupov I.R., Oprikova V.E. Rezultaty laboratornykh issledovanii reologicheskikh kharakteristik sshitogo polimernogo sostava [The results of laboratory studies of the rheological characteristics of the crosslinked polymer composition]. Bulatovskie chteniia, 2018, vol.2, part 2, pp.63-66.

38. Rogachev M.K., Strizhnev K.V. Borba s oslozhneniiami pri dobyche nefti [Fighting Oil Production Complications]. Moscow, Nedrabiznestsentr, 2006, $293 \mathrm{p}$.

39. Elkatatny S.M. Determination the rheological properties of invert emulsion based mud on real time using artificial neural network. SPE Kingdom of Saudi Arabia Annual Technical Symposium and Exhibition. Dammam: Society of Petroleum Engineer, 2016. DOI: $10.2118 / 182801-M S$

40. Jouenne S., Klimenko A., Levitt D. Tradeoffs between emulsion and powder polymers for EOR. SPE Improved Oil Recovery Conference. Tulsa: Society of Petroleum Engineer, 2016. DOI: 10.2118/179631-MS

41. Quintero L., Ponnapati R., Felipe M.J. Cleanup of organic and inorganic wellbore deposits using microemulsion formulations: laboratory development and field applications. Offshore Technology Conference. Houston, Society of Petroleum Engineer, 2017. DOI: $10.4043 / 27653-M S$

42. Gumerov R.R., Gvritishvili T.T., Mardashov D.V., Islamov Sh.R. Laboratornye metody i ustroistva dlia issledovaniia blokiruiushchikh sostavov glusheniia skvazhin [Laboratory methods and devices for the study of blocking compositions killing wells]. Khimicheskaia tekhnika, 2018, no.4, pp.8-10.

43. Musabirov M.Kh., Kuriashov D.A., Garifov K.M., Dmitrieva A.Iu., Abusalimov E.M. Razrabotka strukturoobrazuiushchikh kolloidnykh sistem dlia obrabotki porovo-treshchinovatykh kollektorov [Developing structure-forming colloidal systems for matrix acidizing of porousfractured carbonate]. Oil industry, 2019, no.6, pp.71-73.

44. Galimkhanov A., Okhotnikov D., Ginzburg L., Bakhtin A., Sidorov Y., Kuzmin P., Kulikov S., Veliyev G., Badrawi M. Successful implementation of managed pressure drilling technology under the conditions of catastrophic mud losses in the Kuyumbinskoe field. SPE Russian Petroleum Technology Conference. Moscow, Society of Petroleum Engineer, 2019. DOI: 10.2118/196791-MS

45. Volkov V., Turapin A., Ermilov A., Vasyutkin S., Fomin D., Sorokina A. Experience of gas wells development in complex carbonate reservoirs in different stages of development. SPE Russian Petroleum Technology Conference. Moscow, Society of Petroleum Engineer, 2019. DOI: $10.2118 / 196915-R U$

\section{Библиографический список}

1. Complex algorithm for developing effective kill fluids for oil and gas condensate reservoirs / S.R. Islamov, A.V. Bondarenko, G.Y. Korobov, D.G. Podoprigora // International Journal of Civil Engineering and Technology. - 2019. - 10(01). - P. 2697-2713.

2. Исламов Ш.Р., Бондаренко А.В., Мардашов Д.В. Подбор реагентов-эмульгаторов для приготовления инвертно-эмульсионных растворов. Инженер-нефтяник. - М.: Ай Ди Эс Дриллинг, 2018. - № 4. - С. 10-15.
3. Орлов Г.А., Кендис М.Ш., Глущенко В.Н. Применение обратных эмульсий в нефтедобыче. - М.: Недра, 1991. - 224 с.

4. Бойко В.С. Разработка и эксплуатация нефтяных месторождений: учеб. для вузов. М.: Недра, 1990. - 427 с.

5. Черницкий А.В. Геологическое моделирование нефтяных залежей массивного типа в трещиноватых коллекторах / ОАО «РМНТК “Нефтеотдача"». - М., 2002. - 254 с. 
6. Wagle V., Al-Yami A.S., AlSafran A. Designing invert emulsion drilling fluids for HTPT conditions // SPE Kingdom of Saudi Arabia Annual Technical Symposium and Exhibition. Dammam: Society of Petroleum Engineer. - 2018. DOI: $10.2118 / 192192-M S$

7. Hon Chung Lau. Laboratory development and field testing of succinoglycan as a fluid-losscontrol fluid // SPE Drilling \& Completion. Aberdeen: Society of Petroleum Engineer, 1994. DOI: $10.2118 / 26724-P A$

8. Петров Н.А., Соловьев А.Я., Султанов В.Г. Эмульсионные растворы в нефтегазовых процессах. - М.: Химия, 2008. - 440 с.

9. Обоснование алгоритма выбора технологий глушения скважин / П.В. Желонин, Д.М. Мухаметшин, А.Б. Арчиков, А.Н. Звонарев, Н.Н. Краевский, В.Н. Гусаков // Научнотехнический вестник ПАО «НК “Роснефть”». 2015. - № 2. - C. 76-81.

10. Legkokonets V.A., Islamov S.R., Mardashov D.V. Multifactor analysis of well killing operations on oil and gas condensate field with a fractured reservoir // Topical Issues of Rational Use of Mineral Resources. London: CRC Press, 2018. - P. 111-118.

11. Басарыгин Ю.М. Технологические основы освоения и глушения нефтяных и газовых скважин: учеб. для вузов. - М.: Недра, 2001. $-543 \mathrm{c}$.

12. Жидкости глушения для ремонта скважин и их влияние на коллекторские свойства пласта / С.А. Рябоконь, А.А. Вольтерс, В.Б. Сурков, В.Н. Глущенко // ОИ. Серия «Нефтепромысловое дело». - М.: ВНИИОЭНГ, 1989. - Вып. 19. - 42 с.

13. Егорова Е.В., Выборнова Т.С. Анализ опыта разработки жидкостей для глушения и промывки скважин при проведении ремонтновосстановительных работ // Булатовские чтения. - 2018. - Т. 2, ч. 2. - С. 109-112.

14. Мардашов Д.В. Обоснование технологий регулирования фильтрационных характеристик призабойной зоны скважин при подземном ремонте: автореф. дис. ... канд. техн. наук: 25.00.17. - СПб.: Санкт-Петербургский горный институт им. Г.В. Плеханова, 2008. - $130 \mathrm{c}$.
15. Гумерова Г.Р., Яркеева Н.Р. Технология применения сшитых полимерных составов // Нефтегазовое дело. - 2017. - № 2. - С. 63-79.

16. Лейк Л. Справочник инженера-нефтяника. Инжиниринг резервуаров. - М.: Институт компьютерных исследований, 2018. $1074 \mathrm{c}$.

17. Bouts M.N., Ruud A.T., Samuel A.J. Time delayed and low-impairment fluidloss control using a succinoglycan biopolymer with an internal acid breaker // SPE Journal. Texas: Society of Petroleum Engineer. - 1997. DOI: $10.2118 / 31085-\mathrm{PA}$

18. ГОСТ 3900-85. Нефть и нефтепродукты. Методы определения плотности. - М.: Изд-во стандартов, 2006. - 37 с.

19. Foxenberg W.E., Ali S.A., Ke. M. Effects of completion fluid loss on well productivity // SPE Formation Damage Control Symposium. Lafayette: Society of Petroleum Engineer,1996. DOI: 10.2118/31137-MS

20. Chesser B.G., Nelson G.F. Applications of weighted acid-soluble workover fluids // Journal of Petroleum Technology. - New York: Society of Petroleum Engineer, 1979. DOI: 10.2118/7008-PA

21. Глушение скважин блок-пачками эффективное средство сохранения фильтрационных свойств продуктивного пласта / С.А. Демахин, А.П. Меркулов, Д.Н. Касьянов, С.В. Малайко, Д.А. Анфиногентов, Е.М. Чумаков // Нефть и газ Евразии. - 2014. № 8-9. - С. 56-57.

22. Бондаренко А.В., Исламов Ш.Р., Мардашов Д.В. Область эффективного применения жидкостей глушения нефтяных и газовых скважин // Материалы Междунар. науч.-практ. конф. «Достижения, проблемы и перспективы развития нефтегазовой отрасли». - Альметьевск: Альметьевский государственный нефтяной институт, 2017. - Т. 1. - С. 216-221.

23. Овчинников В.П. Жидкости и технологии глушения скважин: учеб. пособие / Тюменский государственный нефтегазовый университет. - Тюмень, 2013. - 96 с.

24. Повышение эффективности глушения скважин Уренгойского месторождения / 
B.В. Дмитрук, С.Н. Рахимов, А.А. Бояркин, Е.Н. Штахов // Нефтяное хозяйство. - 2009. № 4. - С. 2-4.

25. Бакирова А.Д., Шаляпин Д.В., Двойников М.В. Исследование вязкоупругих составов в качестве жидкости глушения скважин // Академический журнал Западной Сибири. - 2018. - № 4. - С. 44-45.

26. Разработка и испытание жидкостей глушения и блокирующих составов на углеводородной основе при капитальном ремонте газовых скважин Уренгойского НГКМ / М.Г. Жариков, Г.С. Ли, А.И. Копылов, Е.В. Минаева, С.Н. Скотнов // Строительство нефтяных и газовых скважин на суше и на море. - 2018. - № 1. - С. 20-23.

27. Bondarenko A.V., Islamov S.R., Mardashov D.V. Features of oil well killing in abnormal carbonate reservoirs operating conditions // 15th Conference and Exhibition Engineering and Mining Geophysics 2019. Gelendzhik: European Association of Geoscientists and Engineers, 2019. - P. 629-633.

28. Sharath S., Donald W., Jonathan W. Acid-soluble lost circulation material for use in large, naturally fractured formations and reservoirs // SPE Middle East Oil \& Gas Show and Conference. - Manama: Society of Petroleum Engineer, 2017. DOI: 10.2118/183808-MS

29. Рябоконь C.A. Технологические жидкости для заканчивания и ремонта скважин / ОАО НПО «Бурение». - Краснодар, 2009. - 337 с.

30. Токунов В.И. Технологические жидкости и составы для повышения продуктивности нефтяных и газовых скважин. - М.: Недра, 2004. - 711 с.

31. An organic "Clay Substitute" for nondamaging water base drilling and completion fluids / P.W. Fischer, J.P. Gallus, R.F. Krueger, D.S. Pye, F.J. Simmons, B.E. Talley // Fall Meeting of the Society of Petroleum Engineers of AIME / Society of Petroleum Engineer. - Nevada, 1973. DOI: $10.2118 / 4651-M S$

32. Dorman J., Udvary F. Comparative evaluation of temporary blocking fluid systems for controlling fluid loss through perforations // SPE Formation Damage Control Symposium. Lafayette: Society of Petroleum Engineer, 1996. DOI: 10.2118/31081-MS
33. Dandekar A.Y. Petroleum reservoir rock and fluid properties. - Boca Raton: CRC press, 2013. - $544 \mathrm{p}$.

34. Стрижнев К.В. Ремонтно-изоляционные работы в скважинах: Теория и практика. СПб.: Недра, 2010. - 560 с.

35. Islamov S.R., Bondarenko A.V., Mardashov D.V. Substantiation of a well killing technology for fractured carbonate reservoirs // Youth Technical Sessions Proceedings: VI Youth Forum of the World Petroleum Council - Future Leaders Forum. London: CRC Press, 2019. - P. 256-264.

36. ГОСТ 1929-87. Нефтепродукты. Методы определения динамической вязкости на ротационном вискозиметре. - М.: Изд-во стандартов, 2002. - 7 с.

37. Раупов И.Р., Оприкова В.Е. Результаты лабораторных исследований реологических характеристик сшитого полимерного состава // Булатовские чтения. - 2018. - Т. 2, ч. 2. C. 63-66.

38. Рогачев М.К., Стрижнев К.В. Борьба с осложнениями при добыче нефти. - М.: НедраБизнесцентр, 2006. - 293 с.

39. Elkatatny S.M. Determination the rheological properties of invert emulsion based mud on real time using artificial neural network // SPE Kingdom of Saudi Arabia Annual Technical Symposium and Exhibition. Dammam: Society of Petroleum Engineer, 2016. DOI: $10.2118 / 182801-\mathrm{MS}$

40. Jouenne S., Klimenko A., Levitt D. Tradeoffs between emulsion and powder polymers for EOR // SPE Improved Oil Recovery Conference. - Tulsa: Society of Petroleum 2016. DOI: $10.2118 / 179631-\mathrm{MS}$

41. Quintero L., Ponnapati R., Felipe M.J. Cleanup of organic and inorganic wellbore deposits using microemulsion formulations: laboratory development and field applications // Offshore Technology Conference. - Houston: Society of Petroleum Engineer, 2017. DOI: 10.4043/27653-MS

42. Лабораторные методы и устройства для исследования блокирующих составов глушения скважин / Р.Р. Гумеров, Т.Т. Гвритишвили, Д.В. Мардашов, Ш.Р. Исламов // Химическая техника. - 2018. - № 4. - С. 8-10. 
43. Разработка структурообразующих коллоидных систем для обработки поровотрещиноватых коллекторов / М.Х. Мусабиров, Д.А. Куряшов, К.М. Гарифов, А.Ю. Дмитриева, Э.М. Абусалимов // Нефтяное хозяйство. 2019. - № 6. - C. 71-73.

44. Successful implementation of managed pressure drilling technology under the conditions of catastrophic mud losses in the Kuyumbinskoe field / A. Galimkhanov, D. Okhotnikov, L. Ginzburg, A. Bakhtin, Y. Sidorov, P. Kuzmin,
S. Kulikov, G. Veliyev, M. Badrawi // SPE Russian Petroleum Technology Conference. Moscow: Society of Petroleum Engineer, 2019. DOI: $10.2118 / 196791-\mathrm{MS}$

45. Experience of gas wells development in complex carbonate reservoirs in different stages of development / V. Volkov, A. Turapin, A. Ermilov, S. Vasyutkin, D. Fomin, A. Sorokina // SPE Russian Petroleum Technology Conference. Moscow: Society of Petroleum Engineer, 2019. DOI: $10.2118 / 196915-R U$

Please cite this article in English as:

Bondarenko A.V., Islamov S.R., Ignatyev K.V., Mardashov D.V. Laboratory studies of polymer compositions for well-kill under increased fracturing. Perm Journal of Petroleum and Mining Engineering, 2020, vol.20, no.1, pp.37-48. DOI: $10.15593 / 2224-9923 / 2020.1 .4$

Просьба ссылаться на эту статью в русскоязычных источниках следующим образом:

Лабораторные исследования полимерных составов для глушения скважин в условиях повышенной трещиноватости / А.В. Бондаренко, Ш.Р. Исламов, К.В. Игнатьев, Д.В. Мардашов // Вестник Пермского национального исследовательского политехнического университета. Геология. Нефтегазовое и горное дело. - 2020. - Т.20, №1. C.37-48. DOI: $10.15593 / 2224-9923 / 2020.1 .4$ 